\title{
DEVELOPING AUTHENTIC ASSESSMENT FOR MECHANICAL ENGINEERING SUBJECT OF VOCATIONAL SCHOOL STUDENTS (ESP) AT SMK N 2 OF BENGKULU
}

\author{
Erlian Dwisnu \\ University of Bengkulu \\ erlian_dwisnu@yahoo.co.id
}

\begin{abstract}
This research was aimed to know the appropriate assessment, find out speaking's authentic assessment material and find out the characteristics of authentic speaking assessment model for Mechanical Engineering of Vocational School. The type of research was Research and Development. This study was conducted in Mechanical Engineering subject at SMKN 2 Bengkulu City. The sample was taken from third class of Mechanical Engineering students. The data was collected by using questionnaire. The result of the study showed that; first, the appropriate assessment for Mechanical Engineering students Section of Vocational School in SMK N 2 of Bengkulu city was Authentic Assessment. Second, the researcher found 4 kinds of speaking's authentic assessment for Mechanical Engineering. It can be clasified into role play, presentation, picture cued and debate. Third, the characteristics of authentic speaking assessment model for students and teachers of Mechanical Engineering at SMKN 2 of Bengkulu city were topic of assessment, social function format, type of authentic assessment, instrument of authentic assessment, types of rating scale/rubric and times.
\end{abstract}

Keywords: English for specific purpose (ESP), Developing Assessment, Authentic Assessment

\section{INTRODUCTION}

English is one of the compulsory subjects which available in every section at Vocational school of Bengkulu city likes; electricity section building section, and Engineering section. However, to accommodate need of students in study English, the Vocational school of Bengkulu provides English for Specific Purposes for all students of non-English section.

Accordingly, as one of the famous Vocational School in Bengkulu, SMK N 2 has been implemented the study of English as specific purpose. Mechanical Engineering is one of section which study English as a compulsory subject. ESP is importance for Mechanical Engineering of Vocational School in SMK N 2 of Bengkulu city, because it is one of the purposes of learning the English language itself is to prepare the young generation of Indonesia to compete globally. So that the younger generation can later be equipped to interact extensively with international language skills are good and right. In the curriculum, learning objectives English is to produce learners who are able to use Perfomative English language, functional, and epistemic.

Consequently, there was a need for assessing ESP students who need proficiency in both language skills and their section of the study. Thus the ESP approach provides opportunities to the students to acquire their specific purposes that concern on the talent to achieve particular communicative tasks. An assessment becomes one of the famous aspects in ESP approach. Assessment occupies a famous 
position in the ESP process, where provide ESP teacher prosperity of information on the effectiveness and quality of learning and teaching. Dudley-Evans and John (1998) mention that assessment is a process of measuring students' progress, they mention the reasons for using assessment was giving feedback to the students, the second reason was to improve learning encompasses benefits such as reinforcement and confidence building.

Moreover, assessment is the process of collecting information about something that we are interested in (Bachman, 2004). Sarosdy et al (2006) argue that assessment focuses on testing, measuring or judging the progress and the achievement or the language proficiency of the learners.

Authentic assessment in a task based process setting implies a focus on language mastery (criterion-reference performance) rather than relative performance (norm referenced performance), a focus which Ames and Archer (1988) found to be highly motivating in the classroom, fostering longterm use of learning strategies and helping students form realistic but challenging goals.

There were two types of assessments as the focus on this study, traditional assessments and alternative assessments. Here, the researchers only focus to authentic assessments, because traditional assessments it cannot observe and measured the success in study, especially in Vocational School which more focuses in their section than knowledge. An authentic assessment also had strong relevanced to the scientific approach in accordance with the demands of the learning curriculum 2013. This kind of assessment was able to describe the learning outcome of students in order to observe, question, explore, experiment, build networks, and others (Kemendikbud, 2013).

Furthermore, the assessments that appropriate to measure the students' abilities were authentic assessment. According to Padmadewi (2015) authentic assessments give the students opportunities to use language for real purposes, and in real or realistic situation, and assess their attempt to do so successfully.

The other statement from Cahyaningati (2015) which relate to Padmadewi was that authentic assessment is suitable in assessing PPNS students in learning ESP. However to avoid the subjectivity in assessing the students competencies, teachers should create the scoring criteria. Interreability should be maintained so that some teachers may not give students the impression of rating hard while others are rating easy.

From my observation to the teachers who teach in SMK N 2 on 07 June 2016, some teacher said that the test of English in this Vocational School has been implemented authentic assessment. On the other hand, they were some teacher still using test based on the book only, because some of the English teacher feel that authentic assessment bore bigger burden for them. They had spent more time in assessing students' competence in using English in the classroom.

Moreover, these conditions became factors of the low level of relevance in Mechanical Engineering graduation competence with the demands of employment and the ways they are giving assessments to the students. On this section, it didn't have coordination between one to another teachers in the shame subject. Therefore, they were using different materials in teaching although they teach in 
the same department and just different class. Thus the researcher trusts that, the answer to beat the difficulty of the significant of occupational education on learning outcomes aspect was the growth of authentic assessment.

Finally, the researcher should find the necessary assessment for teachers and students and found the kinds of speaking's authentic assessment material for Mechanical Engineering students throught the proces of developing authentic assessment procedure adapted from Baker (1993) and Herman, Aschbacher, and Winters (1992) and Sugiyono (2013) and also to know the characteristic of speaking authentic assessment model for Mechanical Engineering Section of Vocational School. This research only focused for speaking skill.

\section{METHODOLOGY}

This study is a part of research and development. According to Borg and Gall (2003: 570) a research and development is a research in which focused on developing and validating the use of the product of education. It was conducted in Mechanical Engineering students of Vocational school at SMK N 2 of Bengkulu city. the subjects of the research were third class of Mechanical Engineering Students and teachers. The data was collected in academic 2016/2017 through observation.

\section{RESULT AND DISCUSSION}

\section{Results}

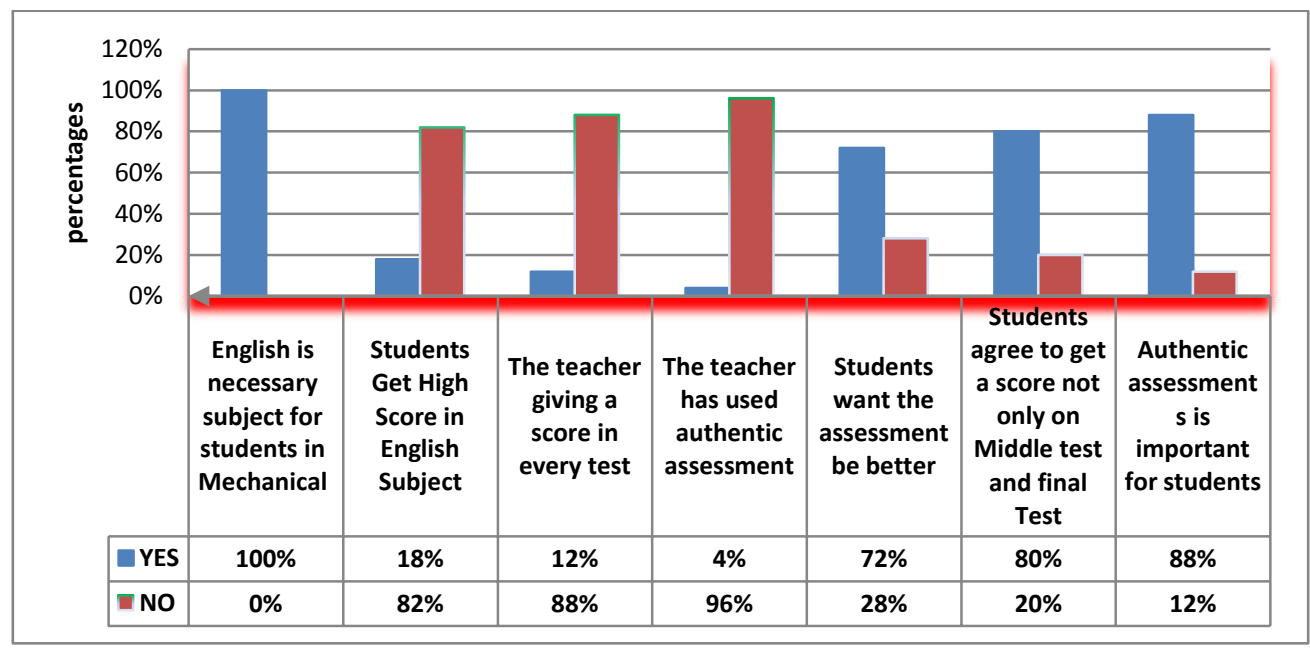

Chart 1: The result of students need analysis

From the chart 4.1 showed that; students agreed that the appropriate assessment was authentic assessments.
Moreover, it can help to improve more specific to need of students subject. 


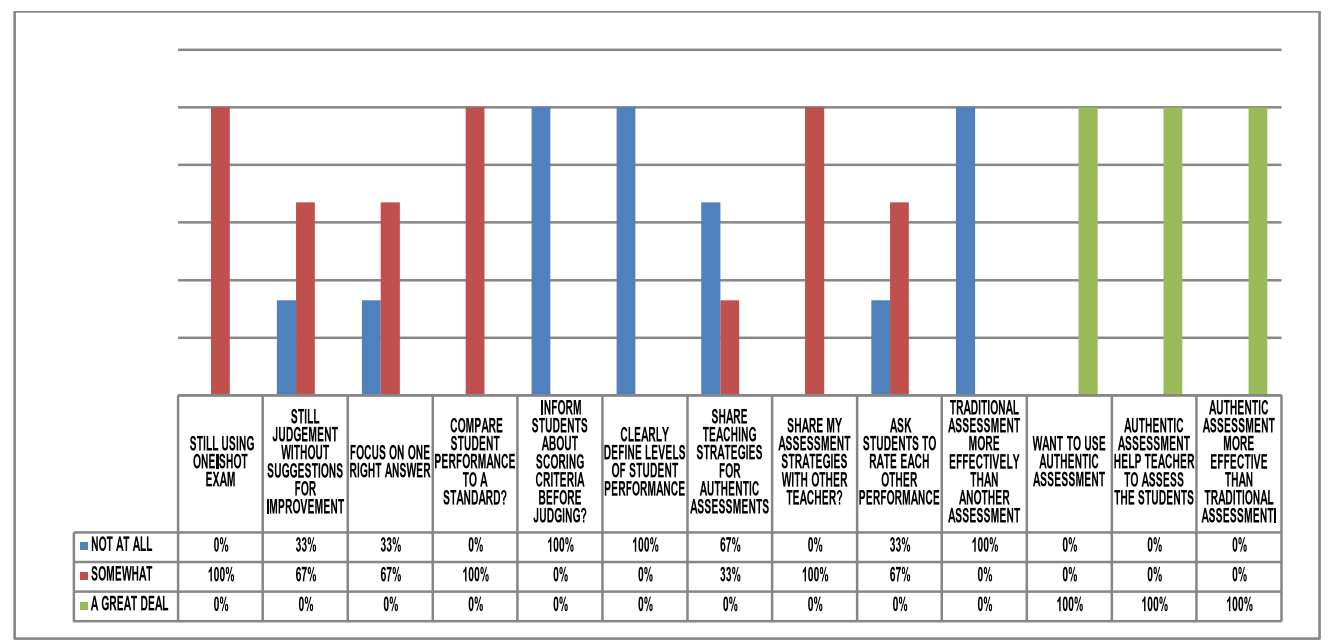

Chart 2: Result of need analysis from teachers

Accordingly, it can be concluded that the teachers and students were need to develop an authentic assessment. It was showed from the percentages of students and teachers need analysis, there were $72 \%$ students want the assessment to be better and there were $88 \%$ students agreed that authentic assessment is important for students.

However, from the analysis of teachers need analysis, there were $100 \%$ teachers agreed that authentic assessment more effectively and authentic assessment helps the teacher to assess the students more effective than traditional assessment.
Result of studied documents on authentic assessment

In the process of developing speaking's authentic assessment material for Mechanical Engineering, the researcher got an authentic assessment material for speaking skills. The following table 5.1 shows speaking's authentic assessment material for Mechanical Engineering.

Table 1 Speaking's Authentic Assessment

\begin{tabular}{|c|l|l|l|l|l|l|l|}
\hline Units & \multicolumn{1}{|c|}{ Topics } & \multicolumn{1}{|c|}{$\begin{array}{c}\text { Social } \\
\text { function }\end{array}$} & Format & $\begin{array}{c}\text { Type of } \\
\text { authentic } \\
\text { assessment }\end{array}$ & $\begin{array}{l}\text { Instrument } \\
\text { of } \\
\text { authentic } \\
\text { assessment }\end{array}$ & $\begin{array}{c}\text { Type of } \\
\text { rating } \\
\text { scale/rubric }\end{array}$ & \multicolumn{1}{|c|}{ Time } \\
\hline $\mathbf{1}$ & $\begin{array}{l}\text { Teks lisan } \\
\text { Untuk menawar } \\
\text { Jasa dan respon }\end{array}$ & $\begin{array}{l}\text { Siswa } \\
\text { menawarkan } \\
\text { jasa dengan } \\
\text { baik,untuk } \\
\text { menjaga } \\
\text { hubungan } \\
\text { interpersonal } \\
\text { dengan } \\
\text { guru,teman, } \\
\text { dan orang } \\
\text { lain. }\end{array}$ & $\begin{array}{l}\text { Pairs, } \\
\text { Group }\end{array}$ & Role plays & $\begin{array}{l}\text { Peer } \\
\text { assessment }\end{array}$ & $\begin{array}{l}\text { Oral language } \\
\text { scoring rubric }\end{array}$ & $\begin{array}{l}4 \times 45 \\
(2 \mathrm{meeting})\end{array}$ \\
& & & & & & & \\
& & & & & & \\
\hline
\end{tabular}




\begin{tabular}{|c|c|c|c|c|c|c|c|}
\hline $\begin{array}{l}\mathbf{a} \\
\mathbf{b} \\
\mathbf{l} \\
\mathbf{e}\end{array}$ & $\begin{array}{l}\text { Tets lisan } \\
\text { untuk } \\
\text { mengawali } \\
\text { penyampaian } \\
\text { berita atau } \\
\text { informasi } \\
\text { yang } \\
\text { mengejutkan }\end{array}$ & $\begin{array}{l}\text { Siswa } \\
\text { menyampaika } \\
\text { n berita atau } \\
\text { informasi } \\
\text { yang } \\
\text { mengejutkan } \\
\text { dengan } \\
\text { baik,untuk } \\
\text { menjaga } \\
\text { hubungan } \\
\text { interpersonal } \\
\text { dengan } \\
\text { guru,teman } \\
\text { dan orang } \\
\text { lain. }\end{array}$ & $\begin{array}{l}\text { Pairs, } \\
\text { groups }\end{array}$ & Role plays & $\begin{array}{l}\text { Peer } \\
\text { assessment }\end{array}$ & $\begin{array}{l}\text { Holistic oral } \\
\text { language } \\
\text { scoring rubric }\end{array}$ & $\begin{array}{l}4 \times 45 \\
\text { (2meeting) }\end{array}$ \\
\hline 3 & $\begin{array}{l}\text { Teks lisan } \\
\text { dan tulis } \\
\text { untuk } \\
\text { meminta } \\
\text { perhatian } \\
\text { 4bersayap } \\
\text { (5extended) } \\
\text { dan } \\
\text { responnya }\end{array}$ & $\begin{array}{l}\text { Meminta } \\
\text { perhatian } \\
\text { dengan } \\
\text { baik,untuk } \\
\text { menjaga } \\
\text { hubungan } \\
\text { interperonal } \\
\text { dengan baik }\end{array}$ & $\begin{array}{l}\text { Pairs/ } \\
\text { Groups }\end{array}$ & Role plays & $\begin{array}{l}\text { Peer } \\
\text { assessment }\end{array}$ & $\begin{array}{l}\text { Holistic oral } \\
\text { language } \\
\text { scoring rubric }\end{array}$ & $\begin{array}{l}4 \times 45 \\
\text { (2meeting) }\end{array}$ \\
\hline 4 & $\begin{array}{l}\text { Teks khusus } \\
\text { lisan } \\
\text { berbentuk } \\
\text { surat lamaran } \\
\text { pekerjaan }\end{array}$ & $\begin{array}{l}\text { Mengungkap } \\
\text { kan ungkapan } \\
\text { yang lazim } \\
\text { digunakan } \\
\text { oleh sumber- } \\
\text { sumber } \\
\text { otentik:surat } \\
\text { lamaran kerja }\end{array}$ & Individual & Presentations & $\begin{array}{l}\text { Self- } \\
\text { assessment }\end{array}$ & $\begin{array}{l}\text { Holistic oral } \\
\text { language } \\
\text { scoring rubric }\end{array}$ & $\begin{array}{l}4 \times 45^{\prime} \\
\text { (2meeting) }\end{array}$ \\
\hline 5 & $\begin{array}{l}\text { Teks } \\
\text { pernyataan } \\
\text { gambar } \\
\text { (caption) }\end{array}$ & $\begin{array}{l}\text { Memberikan } \\
\text { informasi } \\
\text { yang terdapat } \\
\text { dalam gambar }\end{array}$ & $\begin{array}{l}\text { Pairs } \\
\text { /individual }\end{array}$ & $\begin{array}{l}\text { Picture - } \\
\text { cued } \\
\text { descripti } \\
\text { ons }\end{array}$ & $\begin{array}{l}\text { Peer } \\
\text { assessment } \\
\text { and self } \\
\text { assessment }\end{array}$ & $\begin{array}{l}\text { Holistic oral } \\
\text { language } \\
\text { scoring rubric }\end{array}$ & $\begin{array}{l}\times 45^{\prime} \\
\text { (2meeting) }\end{array}$ \\
\hline 6 & $\begin{array}{l}\text { Teks ilmiah } \\
\text { factual (teks } \\
\text { yang } \\
\text { berisikan } \\
\text { tentang } \\
\text { benda, } \\
\text { binatang dan } \\
\text { gejala/peristi } \\
\text { wa alam } \\
\text { terkait dengan } \\
\text { mata } \\
\text { pelajaran } \\
\text { lain) } \\
\end{array}$ & $\begin{array}{l}\text { Menguraikan } \\
\text { gambaran } \\
\text { umum } \\
\text { tentang gejala } \\
\text { alam,sosial, } \\
\text { dan benda- } \\
\text { benda buatan } \\
\text { manusia } \\
\text { secara } \\
\text { objektif dan } \\
\text { ilmiah. }\end{array}$ & Individual & Oral report & $\begin{array}{l}\text { Self } \\
\text { assessment }\end{array}$ & $\begin{array}{l}\text { Holistic oral } \\
\text { language } \\
\text { scoring rubric }\end{array}$ & $\begin{array}{l}4 \times 45 \\
\text { (2meeting) }\end{array}$ \\
\hline 7 & $\begin{array}{l}\text { Teks lisan } \\
\text { untuk } \\
\text { menanyakan } \\
\text { dan } \\
\text { menyatakan } \\
\text { keharusan }\end{array}$ & $\begin{array}{l}\text { Menyatakan } \\
\text { dan } \\
\text { menanyakan } \\
\text { keharusan } \\
\text { untuk } \\
\text { menyarankan } \\
\text { dan } \\
\text { mengingatkan }\end{array}$ & Pairs & Role plays & $\begin{array}{l}\text { Peer } \\
\text { assessment }\end{array}$ & $\begin{array}{l}\text { Holistic oral } \\
\text { language } \\
\text { scoring rubric }\end{array}$ & $\begin{array}{l}4 \times 45 \\
\text { (2meeting) }\end{array}$ \\
\hline 8 & $\begin{array}{l}\text { Teks lisan } \\
\text { untuk } \\
\text { menyatakan } \\
\text { dan } \\
\text { menanyakan } \\
\text { fakta,pendapa } \\
\text { t dan } \\
\text { responnya }\end{array}$ & $\begin{array}{l}\text { Menyatakan } \\
\text { dan } \\
\text { menanyakan } \\
\text { keharusan } \\
\text { untuk } \\
\text { menyarankan } \\
\text { dan } \\
\text { mengingatkan }\end{array}$ & $\begin{array}{l}\text { Individual/ } \\
\text { groups }\end{array}$ & Debate & $\begin{array}{l}\text { Peer } \\
\text { assessment } \\
\text { and self } \\
\text { assessment }\end{array}$ & $\begin{array}{l}\text { Holistic oral } \\
\text { language } \\
\text { scoring rubric }\end{array}$ & $\begin{array}{l}4 \times 45 \\
\text { (2meeting) }\end{array}$ \\
\hline & \multicolumn{7}{|l|}{$\begin{array}{l}\text { Final } \\
\text { examination }\end{array}$} \\
\hline
\end{tabular}


However, from eight steps that used to develop speaking's authentic assessment material for Mechanical Engineering, the team was found 4 kinds of speaking's authentic assessment material in step 5 adapting authentic assessment. From that result, It can be classified into; role play, presentation, picture cued and debate as an authentic assessment material for speaking skill that used in Mechanical Engineering.

\section{Result of the characteristics of speaking's authentic assessment material}

The result showed that, the characteristic of speaking's authentic assessment material for Mechanical Engineering students in SMKN 2 of Bengkulu city contains of seven characteristics that found from the result of speaking's authentic assessment material for Mechanical Engineering of Vocational School, they were; topics, social function, kind of authentic assessment, format, instrument of authentic assessment, rating scale, and time. all of the characteristic have been implemented on the material of speaking's authentic assessment for Mechanical Engineering.

\section{Discussion}

The first question in this research was what is the necessary assessment for Mechanical Engineering students and teacher is authentic assessment. The results showed that the majority of students and teachers have similar problems. However, it showed that the students and teachers need more effective assessments to apply for assessing students' abilities in using English as foreign language. As mentioned by Shohamy (2001 in McKay, 2006), assessment has the power to change people's lives. The effect of assessment may be positive or negative depending on a number of factors, ranging from the way the assessments procedure is constructed, to the way it is used. The effective assessment procedures are assessments that have been designed to ensure, as far as possible valid and fair information on the students' abilities and progress (McKay, 2006).

Furthermore, the effective assessment that found from the result of students and teachers questionnaire was the authentic assessments. It was explained on the result of teachers and students questionnaire.

However, there were only $4 \%$ students said that teacher has used authentic assessment, $72 \%$ students want the assessment be better and $88 \%$ students agreed that authentic assessment is important. Moreover, it was supported by statements of teachers that showed, the majority of teachers said that authentic assessment more effectively and authentic assessments help the teachers to assess the student's better than traditional assessment. The researcher thought that authentic assessments would solve the problem in this subject. It was because this school have implemented curriculum 2013 in teaching learning process at school.

Although, in this school did not use authentic assessment effectively, but the majority of teachers have understood the mechanical of using curriculum 2013 that have relevance to the scientific approach in accordance with demands of using authentic assessment.

The second question is what kinds of speaking's authentic assessment material for Mechanical Engineering are role play, presentation, picture cued and debate. 
Moreover, O Malley (1996) proposed some steps for assessing oral language, including identifying purpose, planning for assessment, developing rubrics and scoring procedures and setting standards. on this step the researcher was found the kinds of authentic assessment for speaking skilll of Mechanical Engineering, they were: First, role play assign distinct roles to each students and ask them to speak through these roles.role plays tend to be more structured than improvisations but less scripted than plays.

Second, presentation can be performed by students individually. They can present many topics related to the learning outcomes of their department. Third, picture-cued can be used for assessment of individual students and are probably most appropriate for beginning and intermediate learners. Fourth, debate can present opportunities for language for a purpose: to convincingly defend one side of an issue.

The third questione is what are the characteristic of speaking's authentic assessment material for Mechanical Engineering are; the first was topic of assessment. Second was social function. The third was format, the fourth was type of authentic assessment and the fifth was instrument. The sixth was types of rating scale/rubric. The last was time. It was showed just a little differences characteristic of authentic speaking assessment for Mechanical Engineering of Vocational School. According to surya there were some characteristic that found in authentic writing assessment, there were; (1) topic, (2) tasks, (3) descriptions of the procedures, (4) authentic assessment, (5) scoring rubric.

\section{CONCLUSION}

Based on data analysis in chapter four, it can be concluded that; first the necessary assessment for students and teachers in Mechanical Engineering subject was authentic assessment. Therefore, the authentic assessment has to be applied more effectively in classroom.

However, there are 8 steps that used in Mechanical Engineering subject at SMK N 2 of Bengkulu city, that are; (1) build a team, (2) determine the purpose of authentic assessment, (3) specify objectives, (4) collect examples of assessments, (5) adapt existing assessments, (6) validating the assessment, (7) Try out the assessment and step 8 final product. From the eight steps, step 5 adapt existing assessment has been important element in this procedure, because form this procedure it can be found 4 kinds of speakings' authentic assessment for Mechanical Engineering of Vocational school, they were; Role play, presentation, picture cued and debate as a kinds of speaking's authentic assessment that used in Mechanical Engineering.

Third, the characteristic of authentic speaking assessment model in Mechanical Engineering students at SMK N 2 of Bengkulu city were; the first was topic of assessment. Second was social function. The third was format, the fourth was type of authentic assessment and the fifth was instrument. The sixth was types of rating scale/rubric. The seventh was time.

\section{SUGGESTION}

After finishing this research, the writer suggests:

For the teachers 
English teachers can give the students an appropriated assessment that necessary to their subject. So that, it will make students more interested and active doing the assessment. Need analysis should be one of the most important steps that teachers have to be references in developing the assessments. Thus, it can be suitable for the students.

For further researchers who want to conduct the same topic of this research. It should collect some information from need analysis to reach the effective assessment. Moreover, the next researchers also have to consider effective time in trying product to get effective result.

\section{REFERENCES}

Aschbacher, P.R.(1991). Performance Assessment : Sate activity, interest, and concerns. Appuralied Measurement in Education 4(4): 275-288

Bachman, L.F. (1990). Fundamental Considerations in Language Testing. Oxford: Oxford University Press.

Baker, E. L (1993). Questioning the technical quality of performance assessment. The school administration; 50(11), 12-16

Borg and Gall, (2003). Educational Research : Universitas Michigan.

C. Ames and J. Archer (1988). Achievement goals in the classroom: students learning strategies and motivation processes. Journal of educational psychology :260-267.

Cahyaningati Tri desi. (2015). Developing authentic assessment ESP for Engineering studedents: international conference.
Denpasar:

University.

Udayana

Dudley-Evans,T. and John, M.St. (1998).Development in English for specific purposes.Cambridge:

Cambridge university press.

Herman, J.L., Aschbacher, P.R., \& Winters, L. (1992). A Practical Guide to Alternative Assessment. Alexandria Va: Association for Supervision and Curriculum Development.

Kementerian Pendidikan dan Kebudayaan Republik Indonesia. (2013). Jakarta : Departemen Pendidikan dan Kebudayaan.

O Malley, J Michael. 1996. Authentic Assessment for English Language Learner. USA. Addison Wesley Publishing.

Penny Mckay. (2006). Assessing young language learners: Cambridge language assessment series.

Peraturan Pemerintah Republik Indonesia Nomor 19 Tahun 2005 tentang Standar Nasional Pendidikan (2005).

Shohamy.(2001). Language testing: the social dimension. University of Michigan.

Sàrosdy,J. and Bence,T,F. Vadnay,M. (2006) . Applied linguistics 1 for BA students inEnglish. Cambridge: Cambridge university press.

Sugiyono. (2013). Metode Penelitian Kuantitatif, kualitatif, dan $R \& D$. Bandung Alfabeta.

Surya Satyawati. (2015). Authentic assessment on teaching writing: international conference. Denpasar: Udayana University. 